\title{
Business partners: Is it all that good?
}

Much is being written on the management accountant's role as a business partner, yet most of the literature to date is a-critical. This article aims to make a modest contribution towards a more rounded and circumspect view of the phenomenon. Is it actually organisations that promote such change? And could changing the roles endanger organisational performance?

\section{John Burns, Liz Warren, João Oliveira}

The organisational role of many management accountants has changed in the last decade, with evidence abound of so-called business partners, the main remit for whom is solving problems and helping to instil broader commercial astuteness in both day-to-day and strategic decision-making (Burns et al. 2013; CIMA 2009; Simons 2007). There has been much written about the business partner role for management accountants, not least by the professional bodies (CIMA 2009) who clearly wish to develop and promote such "exciting" roles for their members. Indeed, we might question the extent to which business partnering is fuelled as much by the accounting profession's desire to promote new avenues for its members in a highly competitive setting than through something that is driven by organisations or their accountants (Baldvinsdottir et al. 2009). And, as we develop below, we might also question whether the business partner role is necessarily a good thing for organisations, as we highlight some of its potentially less than desirable aspects.

Although data capture and analysis remains as important as ever, business partners have moved on from traditional "scorekeeping" roles, and engage in interaction with colleagues across an array of decision-making scenarios. The boundaries of management accounting have been extended significantly in recent times, and being able to meet the ongoing demands of both identifiable and less obvious informational and decision-making needs will be a key role for tomorrow's management accountants.

Many of today's accounting departments consist of different and potentially separated parts, namely "routine accounting" and "advisory accounting". Routine accounting refers to those specialists who oversee the more straight-forward accounting tasks like external reporting, transaction processing, ledger management, taxation and internal audit. Such tasks remain very important in today's organisations, but advances in IT mean that fewer people are required to do such things. Also, some organisations have gathered their routine accounting in "shared services", while others have even outsourced routine accounting to external providers (CIMA 2008a).

On the other hand, advisory accounting describes the remit of business partners, where many of today's management accountants work out in the field, in and amongst the senior management teams (CIMA 2008a, b). This is where accountants use their financial expertise to assist in the production and analysis of information that will inform all manner of decision makers in their local activities. More specifically, advisory accounting is where business partners ply their know-how to assist colleagues in understanding and integrating both the financial and non-financial implications of what happens in different parts of an organisation. 
Having said this, traditional score-keeping roles and other long-standing traits of the management accountant (e. g. stewardship, compliance, integrity, controllership, and governance) have neither disappeared, nor are they any less crucial. On the contrary, in the wake of the last decade's corporate scandals, enterprise collapses and the enduring global financial instability, such traditional roles have surely never been so critical (Baldvinsdottir et al. 2009). We might ask then how risky it could be to continue to promote the business partnering side of management accounting at the expense of more traditional, and probably less exciting, values of a management accountant (Baldvinsdottir et al. 2010). Moreover, is there a danger in becoming too native to particular non-accounting parts of an organisation, thus compromising the accountant's traditional independent view?

A typical view of the type of roles involving today's business partners might include:

Corporate strategy: being situated at the strategic heart of an organisation, and linking the strategic to the operational

Change management: driving and leading organisational change, proactively rather than merely in a supportive manner

Customer-relationship management: producing and communicating information to continually better understand customer needs

Systems development: influencing the design, management, and continuous development of broad information systems

Risk management: identifying, measuring and monitoring risks; and, where possible, helping to avert such risks and/or minimise their damage

As advisory members of the organisational team, business partners are key agents for driving strategy and shaping value-adding activities throughout an organisation, as well as for instilling an ethos that seeks efficiency and continuous improvement. They are no longer just support staff, but can represent significant generators of business value. It is important to note, however, that management accountants are not alone in this race to become the king-pin of organisational knowledge and business development. There is enough anecdotal evidence around to suggest that accountants are seldom alone when claiming ownership of the business partnering role. For instance, a quick search on the internet for how much the human resources (HR) profession seems to be assuming ownership of the balanced scorecard as its key HR management tool will serve to highlight such threats to the management accountant's position.

Integrating information

Business partners are becoming experts in the preparation, interpretation, and use of wider information sets. Consequently, they can be located at the hub of intra- and extra-organisational information flows. Traditionally, management accountants would normally have spent much of their time undertaking routine data collection, "policing" colleagues for their performance against financial targets, and preparing routine accounting reports. Whereas, as mentioned already, today's business partners engage in more advisory and analytical duties, integrating information from different parts 
of an organisation and explaining the inter-connectivity between non-financial performance measures and more conventional financial measures.

Business partners also integrate daily activity and the pursuit of more strategic organisational goals. This requires a significant investment in relevant information, to be in a position to integrate performance review across departments and across time, as well as to synchronise managers' attention towards both financial and non-financial outputs. They work alongside their non-accounting colleagues, as integral members of eclectic management teams, and continually relate financial and non-financial accounting information to wider information flows within the organisation. But, as highlighted earlier, "going native" presents a potential to compromise the independence of an accountant, and could potentially leave an organization without any reliable "corporate brake" (Baldvinsdottir et al. 2009).

Nevertheless, information integration can assist business managers to see the linkages between localised activities, as well as understand how these activities feed into the underlying financial and strategic performance. This reflects a more general shift in the nature of how managers of today monitor performance $-i$. e., from using predominantly financial and quantitative information to an approach which incorporates at least as much focus on non-financial and qualitative assessment. In so doing, the underlying assumption here is that improvement in non-financial outputs (e. g., product quality and customer satisfaction) will eventually deliver improvements in financial terms which, in turn, will be assessed by the management accountants.

\section{Feed-forward information and forecasting}

The information produced by business partners is generally more feed-forward and strategic than in previous times, and mixes both financial and non-financial outlooks to facilitate sound management decisions. And, in this context, there have been some important innovations in respect of tools at their disposal, such as the balanced scorecard and rolling forecasts.

The aim of forecasting is to arrive at reliable predictions about what the future will hold for an organisation, whereas planning is more concerned with how its future should look like. Management accounting information is increasingly fed into an organisation's forecasting process, with continual comparison between budgeted performance measures, actual results, and forecasts. Increasingly, we have witnessed more criticism being directed at traditional planning and control mechanisms such as basic budgeting, with claims that such tools can very quickly become out-of-date, as shifting circumstances negate the underlying assumptions upon which the original budget was built. Equally, there has been an upturn in the use of forecasts, and business partners seem to have a key role to play in this respect.

However, traditional budgeting has not altogether disappeared; budgets still provide a useful overarching framework for planning ahead at any particular point of time. So, while there is evidence that more organisations are now placing a greater emphasis on forecasts, many do so alongside traditional budgeting. This can place a considerable burden on the responsibilities of business 
partners, if tasked with such developments. Forecasts tend to require a sizeable amount of data from many parts of an organisation, so that the required detail and "localised" information can be produced.

\section{Skills requirements}

In respect of skills requirements, traditional or "technical" accounting skills remain fundamental to a business partner, and are generally assumed to be part of any management accountant's locker of expertise. However, technical skills alone are insufficient for tomorrow's business partners, they also need to be supplemented with both hard and soft skills, such as:

Hard skills:

IT proficiency: ability to assist IT experts and statisticians in the design and development of information systems, integrating the latest technologies

Broad business understandings: a broad commercial acumen, to help less financially-astute colleagues assess performance and make local decisions

Soft skills:

Communication: ability to relate management accounting information to its various users, in a way that is understood by them

Interpersonal: strong interpersonal skills, as well as the competence for nurturing relationships and trust with colleagues across the organisation

Conviction: show strong conviction and persuasion, to push ideas through, and ability to deal with differences in personalities, levels of seniority, and mind-sets

\section{Concluding Comments}

The business partner role for management accountants has been widely discussed in the last few years, not least by the professional bodies (CIMA 2009) who clearly wish to develop and promote such "exciting" roles for their members. Indeed, it would seem appropriate to suggest that the accounting profession is one of the drivers - if not the most dominant one - of the business partner phenomenon, underpinning a professional desire to promote new avenues for its members in a highly competitive setting (Baldvinsdottir et al. 2009).

Not unrelated, the accounting profession would do well to be alert to the observation that they appear to face serious competition from other business professionals (e. g., Human Resources) to assume the business partnering role. 
Finally it might be risky to continue to promote the business partnering side of management accounting at the expense of more traditional - and probably less exciting - values of the traditional management accountant (Baldvinsdottir et al. 2010). For instance, we posited the danger in becoming too "native" to non-accounting parts of an organisation, thus compromising the accountant's independent view.

\section{Literature}

Baldvinsdottir, G./Burns, J./ Nørreklit, H./Scapens, R. W.: The management accountant's role, in: Financial Management, September 2009, pp. 33-4.

Baldvinsdottir, G./ Burns, J./Nørreklit, H./Scapens, R. W.: Risk manager or risqué manager: the new platform for the management accountant, CIMA Research Executive Summary Series, Volume 6 (2010), Issue 2.

Baldvinsdottir, G./Burns, J./Nørreklit, H./Scapens, R. W.: A business partner in the 1960s, in: Payne, R. (Ed.): Finance in the broadest sense, London 2013, pp. 47-53.

Burns, J./Quinn, M./Warren, L./Oliveira, J.: Management Accounting, Maidenhead 2013.

CIMA: Improving decision making in organisations: the opportunity to transform finance, December 2008a.

CIMA: Improving decision making in organisations: unlocking business intelligence, September 2008b.

CIMA: Improving decision-making in organisations: the opportunity to reinvent finance business partners, July 2009.

Simons, P.: Transforming finance, in: Financial Management, November 2007, pp.36-7.

[Marginalia:]

\section{Author information (maximum 200 characters incl. blanks)}

John Burns is Professor of Management \& Accountancy, University of Exeter, Business School (UK) and Visiting Professor at WHU Otto Beisheim Management School (Germany)

Liz Warren is Principal Lecturer in Management Accounting, University of Greenwich (UK)

João Oliveira Is Assistant Professor at the School of Economics and Management, University of Porto (Portugal)

\section{Summary}

- There is a gathering momentum behind the so-called "business partner" phenomena which may need to be questioned regarding their actual contribution to improving organisational performance. 
- The tasks implicated in the business partner role extend considerably beyond those of a more traditional management accountant, but the traditional roles are no less imperative.

- $\quad$ There are numerous challenges ahead and many unknowns for developing the business partner role, not least the necessary skills required and how such skills can be nurtured.

\section{Core theses}

- The idea of business partnering may sometimes be driven by promotion within the accounting profession.

- There are potential risks in over-emphasising business partner roles at the expense of the independence of accountants.

- Accountants are not alone in the professional world for trying to assume the business partnering role in organisations.

- Business partners should facilitate integration amongst different informational sets.

- $\quad$ Business partners need to develop a more feed-forward orientation through the design and use of reliable forecasting tools. 